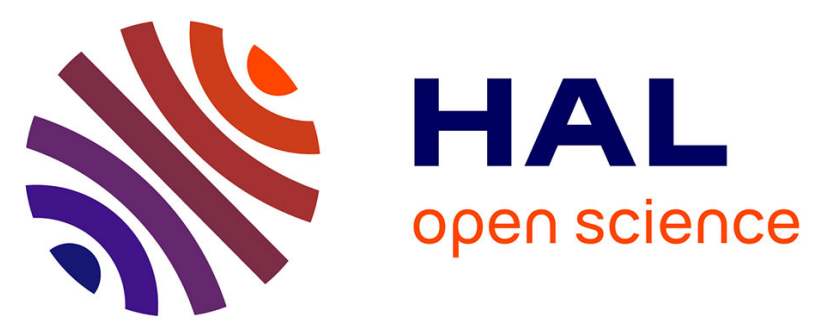

\title{
The 1998 debris avalanche at Casita volcano, Nicaragua: Investigation of the role of hydrothermal smectite in promoting slope instability
}

\author{
Sophie Opfergelt, Pierre Delmelle, Pascal Boivin, Bruno Delvaux
}

\section{- To cite this version:}

Sophie Opfergelt, Pierre Delmelle, Pascal Boivin, Bruno Delvaux. The 1998 debris avalanche at Casita volcano, Nicaragua: Investigation of the role of hydrothermal smectite in promoting slope instability. Geophysical Research Letters, 2006, 33, pp.L15305. 10.1029/2006GL026661 . insu-00385857

\section{HAL Id: insu-00385857 https://hal-insu.archives-ouvertes.fr/insu-00385857}

Submitted on 4 May 2021

HAL is a multi-disciplinary open access archive for the deposit and dissemination of scientific research documents, whether they are published or not. The documents may come from teaching and research institutions in France or abroad, or from public or private research centers.
L'archive ouverte pluridisciplinaire HAL, est destinée au dépôt et à la diffusion de documents scientifiques de niveau recherche, publiés ou non, émanant des établissements d'enseignement et de recherche français ou étrangers, des laboratoires publics ou privés. 


\title{
The 1998 debris avalanche at Casita volcano, Nicaragua: Investigation of the role of hydrothermal smectite in promoting slope instability
}

\author{
S. Opfergelt, ${ }^{1}$ P. Delmelle, ${ }^{1,2}$ P. Boivin, ${ }^{3}$ and B. Delvaux ${ }^{1}$ \\ Received 21 April 2006; revised 15 June 2006; accepted 21 June 2006; published 3 August 2006.
}

[1] Buildup of excess pore water pressure within highly fractured rocks is held responsible for the initiation of the disastrous 1998 debris avalanche at Casita volcano, Nicaragua. Here, we postulate that the presence of smectite clay (up to $50 \mathrm{wt. \%}$ ) in the hydrothermallyaltered bedrock contributed to slope instability. Over decades or more, the clayey material probably (i) acted as an efficient barrier to water infiltration, (ii) progressively decreased shear-strength, and (iii) gradually destabilized the overlying rock mass. These effects are explained by the shrink-swell behavior of the clay-rich bedrock. During intense rainfall, formation of incipient weak failure surfaces in the superficial rock mass could have been favoured due to rapid alteration in the mechanical properties of smectitecontaining clays deposited in fracture, joint and gouge interfaces. Citation: Opfergelt, S., P. Delmelle, P. Boivin, and B. Delvaux (2006), The 1998 debris avalanche at Casita volcano, Nicaragua: Investigation of the role of hydrothermal smectite in promoting slope instability, Geophys. Res. Lett., 33, L15305, doi:10.1029/2006GL026661.

\section{Introduction}

[2] In October 1998, a relatively small collapse $(1.6 \times$ $10^{6} \mathrm{~m}^{3}$ ) of a pre-existing scarp on the southern flank of the dormant Casita volcano, Nicaragua, resulted in a debris avalanche, which quickly transformed into a disastrous debris flow [Sheridan et al., 1999; Scott et al., 2005]. Kerle et al. [2003] concluded that excess pore water pressure within a highly fractured rock mass developed in response to prolonged seasonal rains and Hurricane Mitch's precipitations, and triggered the failure. A prerequisite was the existence of a clay-containing, intensively hydrothermallyaltered bedrock layer which impeded drainage at depth [Kerle et al., 2003].

[3] The nature and amounts of the clay material involved in the 1998 slope failure have not been described. Yet, besides providing an efficient barrier to drainage, certain clays are also considered as a determining factor of slope evolution. For example, smectite clays have been shown to play a role in basal slip-surface development in landslides [e.g., Piteau and Peckover, 1978; Istok and Harward, 1982; Shuzui, 2001], and to contribute to acceleration of rockslide

\footnotetext{
${ }^{1}$ Soil Science Unit, Université Catholique de Louvain, Louvain-laNeuve, Belgium.

${ }^{2}$ Now at Environment Department, University of York, York, UK.

${ }^{3}$ Laboratoire d'Étude des Transferts en Hydrologie et Environnement, Institute of Research for Development, Université Joseph Fourier, Grenoble, France.
}

Copyright 2006 by the American Geophysical Union. 0094-8276/06/2006GL026661 movements [e.g., Parise and Calcaterra, 2000; Jaboyedoff et al., 2004].

[4] In the present study, we report the results of physical, chemical and mineralogical investigations aimed at quantifying the clay fraction and characterising the clay minerals of the hydrothermally-altered rocks uncovered by the 1998 debris avalanche at Casita volcano. The impact that the clay fraction may have had on slope stability is discussed.

\section{Methods}

[5] Casita (1,405 m a.s.1.) is part of the San Cristóbal volcano complex in the Nicaraguan Depression. Autobrecciated lava domes are found at the summit and numerous small fumarole fields occur on nearby slopes [Hazlett, 1987]. The 1998 slope failure took place on the volcano upper southern flank and apparently proceeded as two or more successive failures [Vallance et al., 2004; Scott et al., 2005].

[6] According to Vallance et al. [2004], the initial failure came from the northern part of the scarp where whitish, clayey bedrock (I in Figure 1) is overlaid by fractured lava (II in Figure 1). The second failure site in the southern part of the scarp involved harder, yellowish altered rock (IV in Figure 1) beneath volcanoclastic debris (V in Figure 1). In the central part of the scarp, the debris-avalanche deposits overlaid reddish, highly plastic bedrock (thickness exposed was $\sim 2-3 \mathrm{~m}$ ) exhibiting conspicuous microaggregated facies (VI in Figure 1). Similarly highly altered material outcropped $\sim 400 \mathrm{~m}$ from the headward (north) part of the scarp (VII in Figure 1). The same material also occurred in a $\sim 3 \mathrm{~m}$ thick alteration profile in a fumarole field (VIII in Figure 1), $1250 \mathrm{~m} \mathrm{NE}$ of the failure area. The samples analysed in this study were collected in January 2001 from zones I, IV, VI, VII and VIII.

[7] The altered rock material was air-dried and sieved at $2 \mathrm{~mm}$, and quantitative extraction of clays $(<2 \mu \mathrm{m})$ from the fine earth fraction $(<2 \mathrm{~mm}$; sand + silt+clay $)$ was achieved after dispersion using a $\mathrm{Na}^{+}$-resin [Rouiller et al., 1972]. The cation exchange capacity (CEC) was determined by saturation with $\mathrm{CH}_{3} \mathrm{COONH}_{4}(1 \mathrm{M})$ at $\mathrm{pH} 7$ [Page et al., 1982]. The elemental compositions of the clay and fine earth fractions were measured by inductively coupled plasmaatomic emission spectrometry (ICP-AES) after borate fusion at $1000^{\circ} \mathrm{C}$ and dissolution of fusion beads in $10 \% \mathrm{HNO}_{3}$ [Chao and Sanzolone, 1992]. The structural formulae of the clay minerals were calculated according to Moore and Reynolds [1997]. The mineralogy of the clay fraction was determined by X-ray diffraction (XRD) after physical and chemical treatments [Robert and Tessier, 1974].

[8] The shrink-swell properties of undisturbed clayey clods from zone VII were measured in low moisture tension 


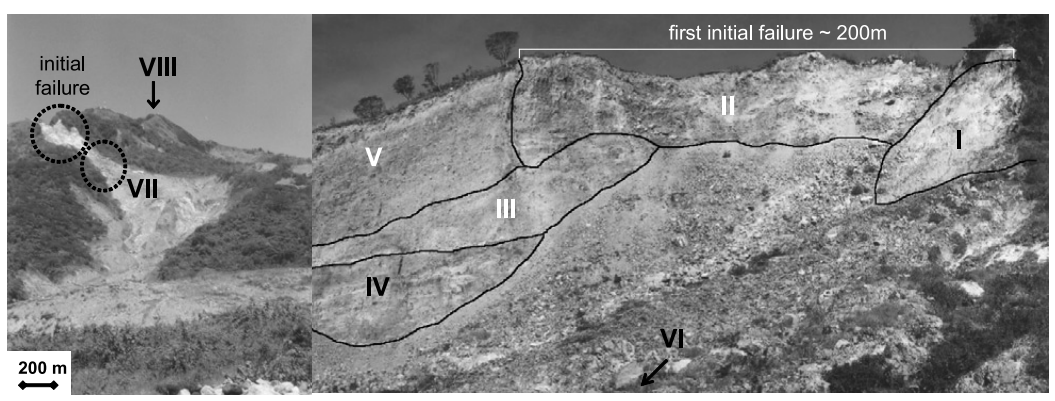

Figure 1. Photographs of the southern flank of Casita volcano sketching the sampling sites (left) outside (zones VII and VIII) and (right) inside (zones I, IV, and VI) the initial failure area. Zones I to V correspond to those described in Figure 5 of Vallance et al. [2004].

(MT) cells [Tessier and Berrier, 1979]. Hydration was induced by equilibration of the clods at three MT values (successively 100, 10, $0.1 \mathrm{kPa}$ ). Five replicates were obtained at each MT value. The bulk volume was determined and the water content ( $\mathrm{g} / \mathrm{g}$ of dry solid) was obtained by heating the sample at $105^{\circ} \mathrm{C}$ for $48 \mathrm{~h}$. The water ratio $\mathrm{e}_{\mathrm{w}}$ (dimensionless) is defined as the ratio of the volume of water to that of the solid.

\section{Results}

[9] The clay contents of the hydrothermally altered rocks from the two initial failure sites (I and IV) were 37 and $10 \mathrm{wt} . \%$, respectively (Table 1), 50 and $38 \%$ in the altered bedrock samples (respectively VI and VII), and 36\% in the rocks from the fumarole field (VIII). The clay content of the fine earth fraction ranged between 40 and 95\% (Table 1). The CEC of the clay fraction was above $50 \mathrm{cmol}_{\mathrm{c}} / \mathrm{kg}$, showing the occurrence of expansible phyllosilicate minerals such as smectite [Borchardt, 1989].

[10] XRD data revealed that the clay fraction of zones I and IV contained both smectite and kaolinite. Smectite was the only clay mineral identified in zones VI, VII and VIII (Table 1). The calculated structural formulae per half unit cell indicated that the smectitic clays pertained to the beidellite-montmorillonite (Mg-rich smectites) series:

$$
\begin{aligned}
& \left\{\mathrm{Si}_{3.38} \mathrm{Al}_{0.62}\right\} \mathrm{O}_{10}\left\{\mathrm{Al}_{1.65} \mathrm{Fe}_{0.19} \mathrm{Mg}_{0.19} \mathrm{Ti}_{0.08}\right\} \mathrm{OH}_{2} \mathrm{Ca}_{0.15} \mathrm{Na}_{0.06} \mathrm{~K}_{0.05} \\
& \left\{\mathrm{Si}_{3.71} \mathrm{Al}_{0.29}\right\} \mathrm{O}_{10}\left\{\mathrm{Al}_{1.28} \mathrm{Fe}_{0.13} \mathrm{Mn}_{0.01} \mathrm{Mg}_{0.79} \mathrm{Ti}_{0.01}\right\} \\
& \mathrm{OH}_{2} \mathrm{Ca}_{0.15} \mathrm{Na}_{0.04} \mathrm{~K}_{0.10}
\end{aligned}
$$

According to the XRD spectra, montmorillonite was the major smectitic clay in zone I, while beidellite was dominant in zones VI, VII and VIII.
[11] As illustrated in Figure 2, $\mathrm{e}_{\mathrm{w}}$ increased from 1.47 to 2.14 (corresponding to $45 \%$ swelling) as MT decreased from 100 to $0.1 \mathrm{kPa}$. Accordingly, the shrink-swell experiment revealed that the water content of the undisturbed clayey material from zone VII increased from 56 to $81 \%$ with decreasing MT (not shown in Figure 2). These results indicate a strong capacity to swell upon wetting, with values typical for a smectite clay previously constrained at MT of $10^{5} \mathrm{kPa}$ [Tessier, 1984] (Figure 2). We also observed that, prior to wetting, abrupt water saturation of the clayey clods (zones VI and VII) led to strong lateral shrinkage, with production of small aggregates showing clear slickenslides on their faces.

\section{Discussion}

[12] Our mineralogical determinations strongly suggest that considerable reduction in water infiltration at depth was achieved by the high clay content (up to $50 \mathrm{wt} . \%$ ) found in the intensively hydrothermally-altered bedrock of the avalanche scarp. This certainly promoted buildup of water pore pressure within the overlying rock mass. Clogging by fine clay particles of pores involved in water drainage is a wellknown phenomenon [e.g., Mesri and Olson, 1971]. However, the pervasive presence of smectite is of note, because swelling of this clay mineral during hydration constitutes a very efficient way to close porosity [Borchardt, 1989].

[13] Alteration of hard volcanic rock into a smectite-rich material on the southern flank of Casita also could have degraded the slope's mechanical performance. Replacement of the rock's primary mineral assemblage by clay minerals typically decreases shear strength [e.g., Anderson and Sitar, 1995; Fredlund et al., 1995; Leroueil and Hight, 2003]. This effect is attributed to the low angle of friction, $\Phi$, of soft clay minerals $\left(\Phi=5-12^{\circ}\right)$ as compared to crystalline

Table 1. Clay Content, Clay Mineralogy, $\mathrm{SiO}_{2} / \mathrm{Al}_{2} \mathrm{O}_{3}$ Molar Ratio and Cation Exchange Capacity (CEC) of the

\begin{tabular}{|c|c|c|c|c|c|}
\hline \multirow[b]{2}{*}{ Zones } & \multirow{2}{*}{$\frac{\text { Bedrock }}{\text { Clay Content, wt. } \%}$} & \multicolumn{2}{|c|}{ Fine Earth Fraction $<2 \mathrm{~mm}$} & \multicolumn{2}{|c|}{ Clay Fraction $<2 \mu \mathrm{m}$} \\
\hline & & Clay Content, wt. $\%$ & $\mathrm{SiO}_{2} / \mathrm{Al}_{2} \mathrm{O}_{3}$ & $\mathrm{CEC}, \mathrm{cmol}_{\mathrm{c}} / \mathrm{kg}$ & Mineralogy \\
\hline I & 37 & 95.4 & 2.09 & 50.02 & sm, kaol \\
\hline IV & 10 & 39.9 & 3.88 & n.d. & sm, kaol \\
\hline VI & 50 & 91.4 & 2.76 & 87.54 & $\mathrm{sm}$ \\
\hline VII & 38 & 94.8 & 2.62 & 79.95 & $\mathrm{sm}$ \\
\hline VIII & 36 & 71.4 & 2.16 & 109.48 & $\mathrm{sm}$ \\
\hline
\end{tabular}
Hydrothermally-Altered Bedrock in the Initial Failure Area (I, IV and VI), Below the Scarp (VII), and in the Fumarole Field (VIII) ${ }^{\mathrm{a}}$

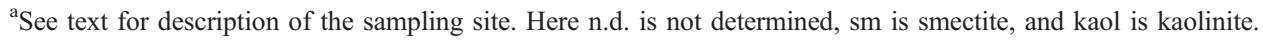




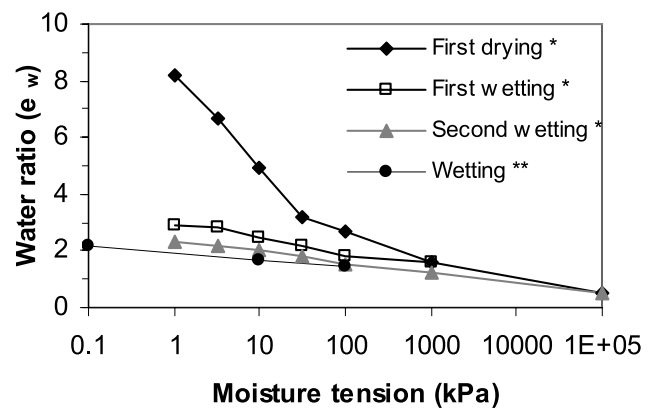

Figure 2. Evolution of the water ratio $\left(\mathrm{e}_{\mathrm{w}}\right)$ as a function of moisture tension $(\mathrm{kPa})$ upon wetting of an undisturbed clod of smectite-rich $(* *)$ bedrock material outcropping on the southern-flank of Casita volcano (zone VII). The behavior of a Ca-smectite $\left(^{*}\right)$ under wetting-drying is shown for comparison [Tessier, 1984].

silica $\left(\Phi=25^{\circ}\right)$ and other alumino-silicates $\left(\Phi=35^{\circ}\right)$ [Fredlund and Rahardjo, 1993]. In fact, smectite is one of the clay minerals with the lowest $\Phi$ value. The impact on shear-strength is expected to be more pronounced for Mgrich smectites [Moore, 1991], such as those found at Casita.

[14] The smectite-containing altered bedrock from the avalanche scarp of Casita showed field (presence of microaggregated facies) and experimental evidence of previous wetting-drying (swell-shrink) cycles. The slickenslides observed upon aggregates faces in clayey clods from zones VI and VII are indicative of swelling pressures exceeding the shear-strength of the material under overburden pressure confinement [Wilding and Puentes, 1988]. The swelling curve (Figure 2) obtained for the undisturbed clayey material from zone VII confirmed this assertion. Compared with the swelling curve reported for a smectite sample [Tessier, 1984], the Casita clay material was inferred to behave like a $10^{5} \mathrm{kPa}$ pre-stressed smectite paste. This constraint can hardly be attributed to air drying, because the moisture tension corresponding to the relative humidity $(\sim 70 \%)$ prevailing in the Casita area is only $\sim 0.510^{5} \mathrm{kPa}$. Thus, it is likely that the smectite-rich bedrock had undergone swelling under mechanical constraint.

[15] As shown earlier, the highly altered rocks involved in the first initial failure site (I) contained up to $37 \mathrm{wt} . \%$ of clay, in the form of smectite and kaolinite. Based on the values of the molar $\mathrm{SiO}_{2} / \mathrm{Al}_{2} \mathrm{O}_{3}$ ratio of the altered rock (Table 1), non-altered andesitic rock $($ ratio $=3.5$ ), kaolinite $($ ratio $=1)$ and montmorillonite $($ ratio $=2.4)$, we estimated that the minimum smectite content in zone I was at least $26 \%$. In zone VI, where beidellite was dominant, smectite content was $\sim 50 \%$ (Table 1 ). These results strongly suggest that the altered material of zone I and VI also had a high potential to swell upon wetting, comparable to the behavior of the clay-rich bedrock in zone VII.

[16] The altered rock least prone to swell outcropped in zone IV. It had the lowest clay content $(\sim 10 \%)$ and contained both smectite and kaolinite. Semi-quantitative XRD analysis indicates smectite as the dominant clay. Accordingly, swelling also affected the material from zone IV. In addition, kaolinite layers can adsorb water molecules and may be subject to volume change upon wetting-drying [Tessier, 1984], although macroscopic swelling resulting from hydration of kaolinite is five times less than that of smectite [Tessier, 1984].

[17] The finding that the smectite-rich altered bedrock in the avalanche scarp had undergone previous swelling cycles has direct implications for slope stability. Alternating swelling and shrinking leads to mineral fatigue, which in turn lowers the angle of friction, thereby reducing rock shear strength [e.g., Leroueil and Hight, 2003]. Besides, the swelling pressure developed upon water uptake by smectites can be several orders of magnitude higher than the hydrostatic pressure produced by water infiltration in rock fractures [e.g., Tessier et al., 1998]. To illustrate this, Van Olphen [1963] calculated that a pressure equivalent to more than $20 \mathrm{~km}$ of rock pile is required to expel the bonded water from the montmorillonite interlayer. If swelling pressure exceeds the shear strength of the material, small displacements may occur as stress is relieved. In general, the material does not return to its initial state during dehydration. Deformation of the ground surface in response to swelling of soil clay minerals is a serious engineering problem in many regions [e.g., Gill et al., 1996]. Based on these considerations, we suggest that swelling of the clayrich hydrothermally-altered bedrock in the pre-failure area is a viable process that contributed to destabilize the overlying rock mass. Such process could have been involved in the formation of the subsidence area in the top of the pre-failure scarp [see Kerle et al., 2003].

[18] However, such phenomenon was gradual as it probably occurred over a period of several tens or hundreds of years. This results from slow equilibration of pore water pressure in clay-rich layers, with equilibration duration increasing with depth. For example, Leroueil [2001] reported equilibration times at various experimental sites ranging from 1 to $10^{5}$ years at depths varying from 10 to $100 \mathrm{~m}$. The question arises whether the century-scale deformation of the southern flank of Casita volcano studied by Kerle and van Wyk de Vries [2001] could be related to shrink-swell processes of smectite-rich material at depth.

[19] The surficial rock mass at the head of the pre-failure area was highly fractured and moderately altered [e.g., Kerle et al., 2003; Vallance et al., 2004]. We also observed hydrothermal alteration features in the boulders deposited by the debris avalanche in the scarp. Thus, the surface of discontinuities (bedding planes, joints, shear zones, fractures) of the fractured rock mass may well have contained clayey material, including smectite. The resulting mechanical effect would have been a reduction in joint shear strength [e.g., Jaboyedoff et al., 2004]. In addition, abrupt saturation of clay following rapid filling of the fracture network during torrential rains could have led to formation of incipient weak failure surfaces in the superficial rock mass, further favouring destabilization.

[20] According to Scott et al. [2005], the initial collapse volume consisted mostly of rock altered in situ containing $\sim 25 \%$ of material $<2 \mathrm{~mm}$. The contribution of the fractured rock mass to this grain size fraction was probably minimal and thus, most of the volume came from the bedrock. Using our data, the volume of clay incorporated in the initial debris avalanche and thus, in the resulting debris flow, may have amounted to $\sim 2.2-5.2 \times 10^{5} \mathrm{~m}^{3}$, or $\sim 14-30 \%$, which is an order of magnitude larger than the estimate cited previously (K. Scott, personal communication cited by 
Kerle et al. [2003]). The clay-rich rock stripped from the head scarp (i.e., zone VII) by the collapse runout [Scott et al., 2005] also was smectite-rich. According to Coussot and Ancey [1999], the rheological behavior of a granular suspension is strongly influenced by the presence of small particles exhibiting repulsive forces (such as smectite). Marked decrease in viscosity and shear strength was observed for granular flows containing only $0.5 \mathrm{wt} \%$ of smectite [Bardou et al., 2004, 2006]. Similarly, incorporation of smectite in the debris avalanche may have played a role in the dynamics of the 1998 Casita debris flow, possibly contributing to increase its hazard.

\section{Concluding Remarks}

[21] The pervasive presence of smectitic clay in the highly hydrothermally-altered bedrock involved in the 1998 slope failure strongly reduced permeability at depth, but also altered the rheological and mechanical properties of the pre-failure rock mass. These effects relate to repeated wetting-drying cycles of smectite clay over a period of several tens to hundreds of years. Similar processes may still be active in the failure scarp as well as in other parts of Casita cone where hydrothermal activity has turned hard bedrock into clayey material. Consideration of the hazard associated with unstable volcanic slopes should include the potential long and short-term impacts of swelling clays. This could be more relevant for volcanoes hosting a longlived hydrothermal system.

[22] Acknowledgments. We gratefully thank the staff of INETER for valuable discussion and support during fieldwork, in particular Pedro Hernandez. We also thank Anne Iserentant and Claudine Givron for laboratory assistance, and Thomas Delfosse and Jérome Hansenne for help in the field. S.O. acknowledges a travel bursary $\left(\mathrm{n}^{\circ} 6 / 20 / \mathrm{b}-\mathrm{CP}-0090\right)$ from the Belgian "Coopération Universitaire au Développement" (CUD). Insightful suggestions in the early stage of this project were provided by Norman Kerle and Kevin Scott. This research was supported by contract 9.4520 .00 of the Belgian "Fonds de la Recherche Fondamentale et Collective" (FNRS-FRFC).

\section{References}

Anderson, S. A., and N. Sitar (1995), Shear strength and slope stability in a shallow clayey soil regolith, in Clay and Shale Slope Instability, Rev. Eng. Geol., vol. 10, pp. 1-11, edited by W. C. Haneberg and S. A. Anderson, Geol. Soc. of Am., Boulder, Colo.

Bardou, E., P. Bowen, P. G. Banfill, and P. Boivin (2004), Dramatical impact of low amounts of swelling clays on the rheology of alpine debris flows, Eos Trans. $A G U, 85(47)$, Fall Meet. Suppl., Abstract H41B-0293.

Bardou, E., P. Bowen, P. Boivin, and P. Banfill (2006), Impact of small amounts of swelling clays on the physical properties of debris flow-like granular materials: Implications for the study of alpine debris flow, Earth Surf. Processes Landforms, in press.

Borchardt, G. (1989), Smectites, in Minerals in Soil Environment, edited by J. B. Dixon and S. B. Weed, pp. 675-717, Soil Sci. Soc. Am., Madison, Wis.

Chao, T. T., and R. F. Sanzolone (1992), Decomposition techniques, J. Geochem. Explor., 44, 65-106.

Coussot, P., and C. Ancey (1999), Rheophysical classification of concentrated suspensions and granular pastes, Phys. Rev. E, 59, 4445-4457.

Fredlund, D. G., and H. Rahardjo (Eds.) (1993), Soil Mechanics for Unsaturated Soils, 576 pp., John Wiley, Hoboken, N. J.

Fredlund, D. G., M. D. A. Xing, M. D. Fredlund, and S. L. Barbour (1995), The relationship of the unsaturated soil shear strength to the soil-water characteristic curve, Can. Geotech. J., 32, 440-448.

Gill, J. D., M. W. West, D. C. Noe, H. W. Olsen, and D. K. McCarty (1996), Geologic control of severe expansive clay damage to a subdivision in the Pierre Shale, southwest Denver metropolitan area, Colorado, Clays Clay Miner., 44, 530-539.

Hazlett, R. W. (1987), Geology of the San Cristobal volcanic complex, Nicaragua, J. Volcanol. Geotherm. Res., 33, 223-230.
Istok, J. D., and M. E. Harward (1982), Clay mineralogy in relation to landscape instability in the Coast Range of Oregon, Soil Sci. Soc. Am. J., 46, 1326-1331.

Jaboyedoff, M., F. Baillifard, E. Bardou, and F. Girod (2004), The effect of weathering on Alpine rock instability, Q. J. Eng. Geol. Hydrogeol., 37, 95-103.

Kerle, N., and B. van Wyk de Vries (2001), The 1998 debris avalanche at Casita volcano, Nicaragua-investigation of structural deformation as the cause of slope instability using remote sensing, J. Volcanol. Geotherm. Res., 105, 49-63.

Kerle, N., B. van Wyk de Vries, and C. Oppenheimer (2003), New insight into the factors leading to the 1998 flank collapse and lahar disaster at Casita volcano, Nicaragua, Bull. Volcanol., 65, 331-345.

Leroueil, S. (2001), Natural slopes and cuts: Movement and failure mechanisms, Geotechnique, 51, 197-243.

Leroueil, S., and D. W. Hight (2003), Behaviour and properties of natural soils and soft rocks, in Characterisation and Engineering Properties of Natural Soils, edited by T. S. Tan et al., pp. 29-254, A. A. Balkema, Brookfield, Vt.

Mesri, G., and R. E. Olson (1971), Mechanisms of controlling the permeability of clays, Clays Clay Miner., 19, 151-158.

Moore, D. M., and R. C. Reynolds (1997), X-Ray Diffraction and the Identification and Analysis of Clay Minerals, 2nd ed., 378 pp., Oxford Univ. Press, New York.

Moore, R. (1991), The chemical and mineralogical controls upon the residual strength of pure and natural clays, Geotechnique, 41, 35-47.

Page, A. L., R. H. Miller, and D. R. Keeney (1982), Methods of Soil Analysis, Part 2. Chemical and Microbiological Properties, 2nd ed., 1159 pp., Am. Soc. Agron. and Soil Sci. Soc. Am., Madison, Wis.

Parise, M., and D. Calcaterra (2000), Debris flow-related fans in weathered crystalline rocks, and the potential hazard in Calabria, Italy, paper presented at International Conference on Debris-Flow Hazards Mitigation: Mechanics, Prediction, and Assessment, Int. Assoc. of Hydraul. Eng. and Res., Taipei.

Piteau, D. R., and F. L. Peckover (1978), Engineering of rock slopes, in Landslides Analysis and Control, edited by R. L. Schuster and R. J. Krizek, pp. 193-228, Transp. Res. Board, Washington, D. C.

Robert, M., and D. Tessier (1974), Méthode de préparation des argiles des sols pour des études minéralogiques, Ann. Agron., 25, 859-882.

Rouiller, J., G. Burtin, and B. Souchier (1972), La dispersion des sols dans l'analyse granulométrique. Méthode utilisant les résines échangeuses d'ions, Bull. Ecole Natl. Super. Agron. Ind. Alimentaires Nancy, 14, 193-205.

Scott, K. M., J. W. Vallance, N. Kerle, J. L. Macias, W. Strauch, and G. Devoli (2005), Catastrophic precipitation-triggered lahar at Casita volcano, Nicaragua: Occurrence, bulking and transformation, Earth Surf. Processes Landforms, 30, 59-79.

Sheridan, M. F., C. Bonnard, R. Carreno, C. Siebe, W. Strauch, M. Navarro, J. C. Cruz Calero, and N. B. Trujillo (1999), Report on the October 30 1998 rockfall/debris avalanche and breakout flow of Casita volcano, Nicaragua, triggered by Hurricane Mitch, Landslide News, 12, $2-4$.

Shuzui, H. (2001), Process of slip-surface development and formation of slip-surface clay in landslides in Tertiary volcanic rocks, Japan, Eng. Geol., 61, 199-219.

Tessier, D. (1984), Etude expérimentale de l'organisation des matériaux argileux: Hydratation, gonflement et structuration au cours de la dessiccation et de la réhumectation, Ph.D. thesis, 361 pp., Inst. Natl. de la Rech. Agron., Univ. Paris VII, Versailles, France.

Tessier, D., and J. Berrier (1979), Utilisation de la microscopie à balayage dans l'étude des sols. Observations de sols soumis à différents pF, Sci. Sol, 1, 67-82.

Tessier, D., M. Dardaine, A. Beaumont, and A. M. Jaunet (1998), Swelling pressure and microstructure of an activated clay with temperature, Clays Clay Miner., 33, 255-267.

Vallance, J. W., S. P. Schilling, G. Devoli, M. E. Reid, M. M. Howell, and D. L. Brien (2004), Lahar hazards at Casita and San Cristobal volcanoes, Nicaragua, U. S. Geol. Surv. Open File, 01-468.

Van Olphen, H. (1963), Compaction of clay sediments in range of molecular particle distances, in Clays and Clay Minerals: Proceedings of the 11th International Conference on Clays and Clay Minerals, vol. 13, edited by W. F. Bradley, pp. 175-187, Elsevier, New York.

Wilding, L. P., and R. Puentes (1988), Vertisols: Their Distribution, Properties, Classification and Management, 193 pp., Texas A\&M Univ., College Station.

P. Boivin, Institute of Research for Development, LTHE, Université J. Fourier, B.P. 53, F-38041 Grenoble Cedex 9, France.

P. Delmelle, Environment Department, University of York, York YO10 $5 \mathrm{DD}, \mathrm{UK}$

B. Delvaux and S. Opfergelt, Soil Science Unit, Université Catholique de Louvain, Place Croix du Sud 2/10, B-1348 Louvain-la-Neuve, Belgium. (opfergelt@sols.ucl.ac.be) 